\title{
MAKNA RITUAL PARUMAN BARONG DI PURA LUHUR NATAR SARI, DESA APUAN, KABUPATEN TABANAN
}

\author{
I Nyoman Bontot ${ }^{1}$ \\ Eakultas Dharma Duta, \\ Institut Hindu Dharma Negeri Denpasar
}

\begin{abstract}
Piodalan ageng ritual in Luhur Natar Sari Temple, its implementation is slightly different from the other temples in general in Bali. A long and complex ritual, beginning with ngelawang ritual to three regencies in Bali, melasti, at the time of the peak of the ritual was attended by dozens of barong and thousands of pemedek. The implementation takes a lot of time, energy and not a small amount for the pemedek involved in the piodalan ageng series. This research proposes three problems, namely the ideology of barong meeting ritual, the form of the barong meeting ritual, and the meaning of barong meeting ritual. The problem is examined with eclectic theory, structuration theory, religious theory, and practical theory.

The presence of dozens of barong and thousands of pemedek on piodalan ageng in Luhur Natar Sari Temple, motivated by the existence of three ideologies, namely theological ideology, political ideology, and economic ideology. The form of barong meeting ritual in the sublime Luhur Natar Sari Temple is a series of nangiang Tapakan Ida Bhatara Sakti ceremonies, chanting to jaba kuta for 42 days, bhatara tedun kabeh or barong meeting, penganyaran, barong dance, and closing ceremonies. The meaning of barong meeting ritual in Luhur Natar Sari Temple is a recitation in accordance with history, withnessing the people up close, pasupati begging for taksu, pujawali, and meeting in noetic terms.
\end{abstract}

Keywords Ideology, Ritual, Barong meeting.

\section{PENDAHULUAN}

Upacara piodalan di Pura Luhur Natar

Sari, Desa Adat Apuan, Kecamatan Baturiti,

Kabupaten Tabanan, dilaksanakan pada

Saniscara Kliwon (Tumpek) Wuku Krulut, setiap enam bulan kalender Bali (210 hari)

sekali. Sesuai dengan tradisi, piodalan ageng

dilaksanakan setiap satu tahun sekali yang diselingi piodalan alit. Prosesi odalan ageng

1 inyoman.bontot@gmail.com 
diawali dengan prosesi pangunyan tapakan Ida Bhatara Sakti kairing menuju ke desadesa dan pura yang ada kaitan di Kabupaten Tabanan, Badung, dan Gianyar, selama 42 hari dimulai pada Hari Raya Galungan hingga hari Buda Pahing Krulut, dan diakhiri dengan prosesi malasti di Pantai Batu Bolong, Desa Canggu, Kabupaten Badung. Pada prosesi pangunyan, Tapakan Ida Bhatara Sakti simpang (mampir) ke Pura Mrajan Agung Puri Marga dan Mrajan Agung Puri Mengwi. Puncak piodalan ageng dihadiri oleh puluhan Tapakan Ratu Gede (barong) dari Kabupaten Tabanan, Badung, Gianyar, Bangli, dan Jemberana, serta ribuan pamedek dari seluruh Bali. Ada perbedaan prosesi pada piodalan ageng di Pura Luhur Natar Sari dengan piodalan di pura lain pada umumnya. Pada puncak piodalan ageng di Pura Luhur Natar Sari, seluruh Tapakan Ida Bhatara napak pertiwi (Bhatara tedun kabeh), sedangkan di pura lain umumnya melinggih di Bale Papelik/Bale Paruman. Kehadiran puluhan barong dengan prosesi Bhatara tedun kabeh di Pura Luhur Natar Sari dikenal sebagai ritual paruman barong (Sudarsana dan Widarsana, 2009; Bontot, 2014).

Prosesi ngelawang Tapakan Ida Bhatara Sakti Pura Luhur Natar Sari menuju pura dan desa-desa yang ada di tiga kabupaten di Bali selama 42 hari, menyita waktu, pengiring, dan perjalanan yang panjang. Perjalanan ngiring Tapakan Ida Bhatara Sakti lunga ngelawang selama 42 hari bisa dilalui pada musim kemarau maupun musim penghujan. Pelungan Tapakan Ida Bhatara Sakti pada musim kemarau, menyebabkan para pengiring kepanasan menempuh perjalanan antara desa yang satu dengan desa lainnya yang cukup jauh. Jika prosesi pengunyan berbarengan dengan musim penghujan, para pengiring akan kehujanan selama dalam perjalanan berjalan kaki yang cukup jauh. Seperti menempuh perjalanan dari Desa Riang Darma di Kecamatan Penebel menuju Pura Puser Tasik, Desa Marga di Kabupaten Tabanan yang berjarak sekitar 10 KM) tanpa berhenti. Demikian juga perjalanan dari Pura Puseh, Banjar Sema, Desa Payangan menuju Pura Luhur Gunung Lebah (Pura Campuhan) Desa Ubud di Kabupaten Gianyar yang berjarak sekitar 12 KM. Namun, para pengiring Tapakan Ida Bhatara Sakti Pura Luhur Natar Sari tetap antusias dan ikhlas ngiring lda Bhatara selama prosesi pelungan, baik pada musim kemarau maupun musim hujan (Bontot, 2014).

Hal yang sama juga dijalani oleh para penyungsung dan pengiring Tapakan Ratu Gede (barong) dan Tapakan Ratu Ayu/Mas (Rangda). Semuanya antusias dan ikhlas nyangre (menyambut) kerauhan (kedatangan) Ida Bhatara Sakti beserta para pengiring di lingkungan desa masing-masing. 
Demikian juga, ikhlas dan antusias ngiring Tapakan Ratu Gede masing-masing lunga (berkunjung) ke Pura Luhur Natar Sari pada saat piodalan ageng. Walaupun jarak yang ditempuh cukup jauh. Seperti dari Kabupaten Jemberana, Kabupaten Bangli, Kabupaten Gianyar, Kabupaten Badung, dan Kabupaten Tabanan menuju Pura Luhur Natar Sari di Desa Apuan, Kecamatan Baturiti.

Selama berlangsungnya piodalan ageng di Pura Luhur Natar Sari, seluruh pengiring Tapakan Ratu Gede dari lima kabupaten di Bali larut dalam kebersamaan dengan Krama Desa Apuan sebagai tuan rumah. Para pengiring barong yang jarak desanya cukup jauh dari Apuan, seperti dari Kabupaten Jemberana, Kabupaten Bangli, Kabupaten Gianyar, dan Kabupaten Badung diberikan tempat di rumah warga sekitar pura untuk menginap, mandi, dan berganti pakaian selama Tapakan Ratu Gede mererepan (menginap) di Pura Luhur Natar Sari.

Hubungan kekerabatan antara pengiring barong yang satu dengan lainnya juga dengan Krama Desa Apuan sangat akrab seperti hubungan saudara. Padahal mereka berasal dari berbagai keluarga dengan sorsinggih (kasta) yang berbeda-beda. Tingkat toleransi masing-masing pengiring barong selama berada di Pura Luhur Natar Sari sangat tinggi. Hal tersebut terlihat ketika beberapa Tapakan Ratu Gede yang datang paling akhir belum mendapatkan tempat melinggih, karena keterbatasan tempat dan banyaknya Tapakan Ratu Gede yang rauh saat puncak piodalan ageng, para pengiring dengan tulus ikhlas menata kembali dengan cara merapatkan linggih sesuhunan.

Pada saat piodalan ageng di Pura Luhur Natar Sari berlangsung, selain pengiring barong, hadir pula para tokoh. Baik para tokoh politik, tokoh/penglingsir puri, tokoh masyarakat, seniman, maupun pejabat publik seperti Camat, Bupati, Gubernur, dan lain-lain. Para tokoh-tokoh tersebut seolah-olah berlomba-lomba hadir di Pura Luhur Natar Sari menebar pesona atau sekedar menampilkan diri sambil maturan punia (menyumbang) (Bontot, 2014).

Para pedagang seperti pedagang makanan, pakaian, aksesoris, bahkan tanaman, dan hewan juga tidak ketinggalan meramaikan areal sekitar Pura Luhur Natar Sari. Banyaknya para pengiring barong dan para pemedek yang hadir saat piodalan ageng, menjadi ajang bagi para pedagang untuk mengadu peruntungan di Pura Luhur Natar Sari selama berlangsungnya odalan ageng. Berdasarkan hasil survei, selama berlangsungnya piodalan ageng Tahun 2019, ada sekitar Rp. 900.000.000,00 uang beredar dari para pedagang yang berjumlah 120 lapak (25 lapak milik pedagang dari Bali 
termasuk dari Desa Apuan dan 95 lapak milik pedagang yang berasal dari luar Bali) (Bontot dan Marsono, 2019).

Berdasarkan uraian pada latar belakang di atas, penelitian ini mengajukan tiga permasalahan, yaitu (1) ideologi apakah yang terkandung di balik ritual paruman barong di Pura Luhur Natar Sari? (2) bagaimanakah bentuk ritual paruman barong di Pura Luhur Natar Sari? dan (3) apakah makna ritual paruman barong di Pura Luhur Natar Sari bagi umat Hindu di Bali?

\section{KAJIAN PUSTAKA, KONSEP, dan LANDASAN} TEORI

Beberapa hasil penelitian terdahulu yang dijadikan acuan dalam penelitian ini diantaranya : Sukarsa (2005), penelitian yang berjudul "Pengaruh Pendapatan Keluarga dan Pemahaman Agama Terhadap Pengeluaran Konsumsi Ritual Masyarakat Hindu di Bali Ditinjau dari Berbagai Dimensi Waktu" menyatakan bahwa banyak atau sedikitnya pendapatan sementara yang diperoleh keluarga akan memengaruhi besar kecilnya pengeluaran upacara di Bali. Dana (2008), penelitian yang berjudul "Paruman Barong di Pura Pucak Padang Dawa Baturiti Tabanan : Perspektif Kajian Budaya" menyimpulkan bahwa paruman barong di Pura Pucak Padang Dawa, sebagaimana halnya paruman barong di Pura Natar Sari
Desa Apuan dan Pura Pucak Kembar, Desa Adat Pacung, Baturiti, mengandung makna yang bersifat multilapis yang meliputi makna religius-magis, sosial, politik, estetik, dan ekonomi. Wijaya (2012), penelitian dengan judul "Manajemen Karya Agung Panca Balikrama di Pura Besakih dan Implikasinya Terhadap Kehidupan Sosial-Ekonomi Masyarakat Besakih Kabupaten Karangasem Provinsi Bali" menyatakan bahwa : (1) Karya Agung Panca Balikrama di Pura Besakih dilaksanakan secara berkesinambungan atas dasar pertimbangan filosofis, historis, teologis, psikologis, dan sosiologis; (2) Manajemen Karya Agung Panca Balikrama di Pura Besakih dibangun menggunakan manajemen sinergi, yaitu perpaduan antara manajemen tradisional dengan manajemen modern, disebut Manajemen Sinergi Karya (disingkat MANSEKAR). dan Bontot (2014), disertasi yang berjudul "Paruman Barong Pada Piodalan Ageng di Pura Luhur Natar Sari, Desa Pakraman Apuan, Kecamatan Baturiti, Kabupaten Tabanan" menyatakan bahwa hadirnya puluhan barong dan ribuan pamedek pada piodalan ageng di Pura Luhur Natar Sari karena adanya ideologi di balik ritual paruman barong, yaitu ideologi teologis (Ketuhanan), ideologi politik, dan ideologi ekonomi, yang merupakan distribusi kekuasaan dari dimensi sosial budaya, dimensi politik, dan dimensi ekonomi. Mengetengahkan konsep ideologi (ide-ide, 
gagasan, dan kepercayaan yang sifatnya sistematis sesuai dengan tujuan yang ingin dicapai dalam ritual paruman barong), ritual (upacara yang dilaksanakana secara berkala, berulang sesuai dengan tradisi), dan paruman barong (berkumpulnya puluhan barong di Pura Luhur Natar Sari menghadiri odalan ageng yang bertujuan untuk nunas pasupati dalam rangka odalan taksu bagi tapakan barong dan rangda, katuran pujawali, dan paruman/rapat secara niskala). Permasalahan dikaji menggunakan teori secara eklektik, yaitu Teori Strukturasi Anthony Giddens, bahwa praktik sosial yang berulang dan terpola dalam lintas ruang dan waktu, menekankan hubungan antara struktur dan pelaku (agen), hubungan antara struktur dan pelaku ini dikenal sebagai teori strukturasi yang diartikan sebagai proses terbentuknya sebuah struktur (Basrowi dan Soenyono, 2004:120-121); Teori Religi J.G. Fraser, masalah-masalah yang tidak dapat pecahkan manusia dengan system dan akal, kemudian dipecahkan dengan magis dan ilmu gaib, sebagaimana wabah pandemik (gerubug) yang melanda masyarakat di wilayah Kerajaan Marga dan Mengwi pada jaman dahulu, diselesaikan dengan ngiring Tapakan Ida Bhatara Sakti ngelawang selama wabah pandemik berlangsung (Koentjaraningrat, 2010); dan Teori Praktik dari Pierre Bourdieu, menyatakan bahwa seseorang yang menguasai kapital dengan habitus yang memadai akan menguasai arena dan memenangkan pertarungan sosial (Fashri, 2007:101).

\section{METODE PENELITIAN}

Penelitian tentang paruman barong pada di Pura Luhur Natar Sari, Desa Apuan, Kecamatan Baturiti, Kabupaten Tabanan adalah penelitian studi kasus yang merupakan jenis penelitiam kualitatif, didukung oleh data kualitatif yang bersumber dari data primer dan data sekunder, menggunakan pendekatan sosiologis. Penelitian dilakukan di Desa Adat Apuan Kecamatan Baturiti Kabupaten Tabanan, lokasi Pura Luhur Natar Sari, dan di beberapa lokasi yang berkaitan dengan Pura Luhur Natar Sari.

Instrumen atau alat penelitian yang digunakan dalam penelitian kualitatif adalah peneliti itu sendiri (Sugiyono, 2012:305). Informan ditentukan menggunakan teknik purposive sampling, yang dikombinasikan dengan teknik snowball sampling. Pengumpulan data menggunakan teknik observasi berperan serta (participant observation), wawancara mendalam, dan studi dokumentasi.

Analisis data dilakukan dengan metode kualitatif. Analisis data kualitatif dilakukan dengan metode interpretasi atau mengungkapkan, menerangkan, menerjemahkan hal-hal yang terselubung 
dalam bahasa atau simbol, sehingga makna yang terkandung dalam objek penelitian dapat dipahami oleh manusia (Poespoprodjo, 1987:192).

\section{HASIL PENELITIAN}

Berdasarkan kajian yang dilakukan, maka hasil penelitian tentang paruman barong di Pura Luhur Natar Sari, Desa Apuan, Kabupaten Tabanan berdasarkan tiga permasalahan yang diajukan, dapat dirumuskan sebagai berikut :

Pertama, ritual paruman barong di Pura Luhur Natar Sari dilatar belakangi oleh ideologi, yaitu ideologi teologis (Ketuhanan), ideologi politik, dan ideologi ekonomi, yang merupakan distribusi kekuasaan, yaitu dimensi sosial budaya, politik, dan ekonomi. Tiga dimensi tersebut merupakan pilar kekuasaan, yaitu dimensi sosial budaya (tadisi, religius) dari distribusi kekuasaan dengan pilarnya rakyat/masyarakat sipil (civil society), dimensi politik dari dimensi kekuasaan dengan pilarnya negara (state), dan dimensi ekonomi dari dimensi kekuasaan dengan pilarnya pasar (market).

Kajian pada ideologi teologis berdasarkan simbol-simbol pemujaan yang ada di Pura Luhur Natar Sari ditujukan kepada Durga Dewi, Sakti Tuhan, ibu alam semesta, dengan tiga manifestasi (Chinmayananda, 1994), yaitu (1) Dewi Maha Saraswati berfungsi sebagai pencipta (creation, to birth), ditandai dengan kehadiran Tapakan Ratu Gede/Ratu Ayu/Mas nunas pasupati (kekuatan) di Pura Luhur Natar Sari; (2) Dewi Maha Laksmi berfungsi sebagai pemelihara (preservation, to nourish) dengan menganugerahkan kesejahteraan kepada umat Hindu, ditandai dengan mempersembahkan pala bija, pala bungkah, dan pala gantung ketika Ida Bhatara Sakti ngunya yang kemudian ditunas (dimohonkan); dan (3) Dewi Maha Kali berfungsi sebagai pelindung (destruction, to protect) ditandai seringnya Tapakan Ida Bhatara Sakti dimohon untuk ngelawang di desa-desa yang tertimpa bencana wabah penyakit (grubug). Pemujaan Durga Dewi dengan tiga manifestasi dan fungsi tersebut menjadikan Pura Luhur Natar Sari sebagai tempat nunas pasupati bagi tapakan barong, dan memohon kesejahteraan dan karahayuan/perlindungan bagi umat Hindu. Hal tersebut menyebabkan puluhan tapakan barong dan ribuan umat Hindu hadir pada setiap piodalan ageng di Pura Luhur Natar Sari.

Kajian pada ideologi politik menyimpulkan kehadiran ribuan pamedek secara berkala di Pura Luhur Natar Sari dapat memudahkan penguasa (khususnya Puri Marga) melakukan penataan dan mengontrol rakyatnya. Berdasarkan hasil penelusuran sejarah Tapakan Ida Bhatara 
Sakti yang distanakan di Pura Puseh Desa Adat Apuan - Jelantik, yang kemudian mendirikan Pura Luhur Natar Sari, sepertinya berlatang belakang politik pada era Kerajaan Marga (Bontot, 2014).

Kajian pada ideologi ekonomi, mengacu pada upacara-upacara besar secara berkala (ritual redistributif) yang dilaksanakan di Bali secara bergantian, dimanfaatkan sebagai salah satu arus perdagangan pada era kerajaan Bali (Geertz, 2000). Piodalan ageng yang membutuhkan sarana-prasarana besar dan kehadiran ribuan pamedek menjadi peluang usaha bagi para pedagang. Bahkan, saat berlangsungnya piodalan ageng di Pura Luhur Natar Sari pada ruang yang paling suci sekalipun (paruman panjang uttama mandala linggih Ida Bhatara) bisa terjadi transaski antara penyungsung Tapakan Ratu Gede (barong) dengan undagi (tukang) dalam memperbaiki (ngaponin) tapakan. Pemanfaatan upacara sebagai arus perdagangan dalam ekonomi makro dikenal sebagai konsumsi dalam negeri (Sukirno, 2007).

Kajian ketiga ideologi (teologi, politik, dan ekonomi) pada ritual paruman barong tersebut, sesuai dengan Teori Praktik dari Pierre Boudieu. Untuk dapat memenangkan pertarungan sosial, sebagaimana dinamika kerajaan-kerajaan di Bali ketika itu, maka Kerajaan (Puri) Marga harus menguasai kapital (simbolik, kultural, sosial, dan ekonomi) dengan habitus (menjadi rutin/ritual) di Pura Luhur Natar Sari (juga di Pura Luhur Pucak Padang Dawa) akan dapat menguasai arena pertarungan (sosial) melalui kehadiran banyak barong dan umat ke pura tersebut.

Kedua, bentuk prosesi upacara piodalan ageng di Pura Luhur Natar Sari terbagi dalam beberapa tahapan, diawali dengan nangiang tapakan Ida Bhatara Sakti, pangunyan ke jaba kuta di tiga kabupaten (Tabanan, Badung, dan Gianyar) selama 42 hari yang diakhiri dengan prosesi malasti ke pantai Pura Batubolong, puncak karya yaitu prosesi Bhatara tedun kabeh (paruman barong) yang dihadiri oleh Tapakan Ratu Gede yang berasal dari lima kabupaten di Bali dengan upacara Panyegjeg Bhuwana, kemudian prosesi panyejeran yang dirangkai dengan wali sasolahan Tapakan Ratu Gede (barong) yang diawali/dibuka (ngendag) oleh Tapakan Ratu Gede dari Pura Desa, Desa Adat Baru, Tabanan dan penutup karya yang ditandai dengan prosesi nyimpen Tapakan Ida Bhatara Sakti Pura Luhur Natar Sari dan didahului nyineb (menutup) wali sasolahan oleh Tapakan Ratu Gede dari Pura Dalem Kediri, Desa Sading, Kabupaten Badung. Prosesi puncak karya di Pura Luhur Natar Sari berbeda dengan prosesi puncak karya di pura lainnya di Bali. Jika pada umumnya puncak karya (katuran pujawali) 
seluruh pralingga Ida Bhatara melinggih di Bale Papelik, maka di Pura Luhur Natar Sari seluruh pralingga Ida Bhatara termasuk Tapakan Ratu Gede (barong) berdiri di pelataran pura (tedun kabeh) membentuk lingkaran mengelilingi upakara Penyegjeg Buwana. Prosesi tersebut menyerupai formasi rapat (meeting), sehingga disebut paruman barong.

Terwujudnya prosesi ritual seperti ngelawang dan paruman niskala tersebut di atas, tidak terlepas dari kepercayaan umat Hindu di wilayah Kerajaan Marga dan Kerajaan Mengwi pada jaman dahulu yang dianggap mampu menetralisir sasab mrana (grubug) seperti mewabahnya penyakit kolera ketika itu. Hal tersebut sesuai dengan Teori Religi yang diungkapkan oleh J.G. Frazer. Bahwa Tapakan Ida Bhatara Sakti Pura Luhur Natar Sari mampu secara gaib menyihir pandemik virus kolera yang sedang mewabah di desa-desa, seperti Desa Petiga, Desa Belayu, Desa Kuwum Ancak, dan masalah lainnya pada saat itu.

Ketiga, Mangku Gede Pura Luhur Natar Sari, Jro Mangku Ketut Mastrum, dalam wawancara pada tanggal 27 Juli 2019, menyatakan :

“Tujuan dari prosesi melancaran/ngunya adalah nyuryanin panjak Ida Bhatara, napak tilas pemargin tapakan sebelum melinggih di Pucak Padang Dawa. Melasti ke
Segara Batubolong bertujuan ngamet tirtha amertha ri telengin segara. Dudonan puncak karya dilaksanakan prosesi Bhatara tedun kabeh, berbeda dengan pucak karya di pura lainnya, seluruh tapakan ngadeg ring penataran mengelilingi upakara penyegjeg bhuwana pada tengah malam. Ada tiga proses upacara yang berlangsung dalam prosesi Bhatara tedun kabeh. Pertama, sinarengan nunas pasupati (taksu) karena bersamaan dengan hari Tumpek Krulut yaitu hari turunnya taksu untuk tapakan barong, rangda, topeng, dan lain-lain. Kedua, sinarengan katuran pujawali. Dan ketiga, Ida Bhatara sami sangkep, maosang indik kerahayuan jagat soang-soang. Pada saat prosesi Bhatara tedun kabeh, masing-masing sesuhunan katunasin tirtha pemuput karya selain tirtha sane katunas ring kahyangan jagat ring Bali. Seluruh tirtha tersebut digabung jadi satu. Kemudian, tirtha punika ketunas oleh para pemedek untuk kerahayuan jagat".

Berdasarkan uraian Jro Mangku Gede Pura Luhur Natar Sari di atas, maka makna dari ritual paruman barong di Pura Luhur Natar Sari, dapat diuraikan sebagai berikut :
a. Prosesi pengunyan memiliki beberapa makna, yaitu : (1) Napak 
tilas dari perjalanan suci Ida Ratu Sakti dan Sira Arya Sentong. Tempat-tempat Ida Ratu Sakti dan Sira Arya Sentong bertapa, sekarang sudah menjadi pura. Pura-pura itulah yang dikunjungi saat prosesi pangunyan/malancaran; (2) Napak tilas perjalanan Tapakan Ida Bhatara Sakti (Bontot, 2014). Sesuai dengan buku Purana Pura Luhur Natar Sari bahwa Tapakan Ida Bhatara Sakti sebelum malinggih di Pura Luhur Natar Sari pernah malinggih di beberapa pura seperti Pura Dalem Abiansemal, Pura Dalem Peed, Pura Bedugul (Pura Subak) Desa Gelagah, Kecamatan Marga, Pura Puser Tasik Marga, Pura Puseh Desa Adat Ole Marga, Pura Puseh Desa Adat Payangan Kecamatan Marga, Pura Puseh Desa Adat Kambangan Baturiti, Pura Pucak Padang Dawa, dan Pura Puseh Desa Adat Tua Kecamatan Marga. Terbatasnya waktu yang tersedia dalam pelaksanaan prosesi pangunyan/malancaran antara Hari Raya Galungan dan piodalan ageng di Pura Luhur Natar Sari yang hanya 42 hari, menyebabkan tidak semua pura-pura tersebut terutama yang jauh, dapat dikunjungi;

Nyuryanin (melihat) keadaan panjak (umat) dan menganugerahkan keselamatan. Prosesi pangunyan/malancaran, juga bermakna bahwa Ida Bhatara memperhatikan dari dekat kesejahteraan panjak (umat) beliau; (4) Ngalawang, yaitu terkait dengan ajaran Lontar Barong Swari; dan (5) sebagai pengganti prosesi upacara nanggluk merana yang biasanya dilaksanakan pada sasih kaenem (sekitar bulan November/Desember).

b. Prosesi melasti bermakna penyucian (pembersihan) dan ngamet tirtha amrtha ri telengin segara (mengambil air suci/air kehidupan di tengah lautan) terkait dengan pelaksanaan piodalan ageng. Mengingat beratnya bobot air suci/air kehidupan tersebut, prosesi Ida Bhatara terlihat seperti layaknya protokoler kenegaraan. Yaitu, saat ke pantai Batubolong Ida Bhatara Pura Luhur Natar Sari diiringi sekitar tujuh Tapakan Ratu Gede (barong). Ketika kembali, sesampai di Pura Puseh Desa Adat Tua, disambut (kesangra) oleh Tapakan Ratu Gede Desa Adat Petiga, dijemput (kapendak) oleh Tapakan Ratu Gede Desa Riang Darma, dan sesampainya di Pura Luhur Natar Sari disambut 
(kesangra) oleh Tapakan Ratu Gede

Pura Dalem Kediri Desa Sading,

Tapakan Ratu Gede Pura Desa Baru, dan Tapakan Ratu Alit Pura Pucak Penenjoan Desa Adat Apuan.

c. Bhatara tedun kabeh (paruman barong) memiliki tiga makna, yaitu : makna pasupati kekuatan taksu, makna pujawali, dan makna paruman niskala. Piodalan ageng di Pura Luhur Natar Sari berbarengan dengan hari suci Tumpek Krulut, di Bali dikenal sebagai Piodalan Taksu. Menurut Sudarsana (2003:90-92), Krulut berasal dari kata Kalulut yang bermakna terpikat. Dengan demikian, kata Krulut dapat diartikan sebagai kekuatan pengikat atau kekuatan taksu (karisma). Makna Tumpek Krulut dipandang dari Tattwa (filsafat) Samkya, ada enam kekuatan taksu yang disebut Sadguna, yaitu (1) kekuatan taksu semua jenis barong; (2) kekuatan taksu semua macam dan bentuk alat musik dan kulkul (kentongan); (3) kekuatan taksu punta (punakawan); (4) kekuatan taksu semua jenis Rangda; (5) kekuatan taksu semua bentuk tapel; dan (6) kekuatan taksu semua macam tarian Sanghyang, termasuk Calonarang. Dari uraian tentang Tumpek Krulut tersebut, pada piodalan ageng di Pura Luhur Natar Sari yang bersamaan dengan hari suci Tumpek Krulut, seluruh pralingga, pelawatan Ida Bhatara yang hadir katuran piodalan bersamaan memohon kekuatan taksu kepada Bhatara Siwa (Siwa Nataraja) sebagai dewanya Taksu. Makna paruman niskala, dapat terlihat ketika masing-masing sesuhunan yang hadir (rauh) mempersembahkan tirtha, yang kemudian dicampur menjadi satu, kemudian dibagi kembali. Hal tersebut dapat bermakna bahwa semua sesuhunan yang hadir menyampaikan pendapat dan menerima hasil kesepakatan secara bersama. Menurut yang diyakini oleh Jro Mangku Gede Pura Luhur Natar Sari, yang dibahas dalam paruman niskala tersebut adalah kerahyuan (keselamatan) seluruh umat beliau.

\section{PENUTUP}

\section{SIMPULAN}

Berdasarkan kajian yang dilakukan, maka penelitian ini dapat disimpulkan sebagai berikut : (1) hadirnya puluhan barong dan ribuan pamedek di Pura Luhur Natar Sari, dilatarbelakangi oleh tiga ideologi, yaitu ideologi teologi, ideologi 
politik, dan ideologi ekonomi; (2) bentuk ritual paruman barong di Pura Luhur Natar Sari adalah rangkaian upacara nangiang tapakan Ida Bhatara Sakti, pangunyan ke jaba kuta di tiga kabupaten (Tabanan, Badung, dan Gianyar) selama 42 hari yang diakhiri dengan prosesi melasti ke pantai Pura Batubolong, puncak karya yaitu prosesi Bhatara tedun kabeh (paruman barong) dengan upacara Panyegjeg Bhuwana, kemudian prosesi panyejeran yang dirangkai dengan wali sasolahan Tapakan Ratu Gede (barong); dan (3) makna dari ritual paruman barong pada piodalan ageng di Pura Luhur Natar Sari ada tiga, yaitu memohon taksu, pujawali, dan paruman niskala.

\section{DAFTAR PUSTAKA}

Atmadja, Nengah Bawa. 2011. IImu Agama (Hindu) dan Antropologi Agama. Makalah disampaikan pada matrikulasi Program Pascasarjana S3 IImu Agama IHDN Denpasar 5 Agustus 2011.

Balandier, Georges. 1986. Antropologi Politik (Terjemahan). Jakarta : Rajawali.

Basrowi, Mohammad dan Soenyono. 2004. Teori Sosial Dalam Tiga Paradigma. Surabaya : Yayasan Kampusina. Bontot dan Marsono. 2019. Paruman Barong Ritual Management in Pura Luhur Natar Sari, Apuan Village,
Tabanan Regency. International Journal Contemporary Research Review (IJCRR).

Bungin, M. Burhan. 2010. Penelitian

Kualitatif : Komunikasi, Ekonomi Kebijakan Publik, dan IImu Sosial Lainnya. Jakarta : Kencana Prenada Media Group.

Chinmayananda, Swami. 1994. Glory of the Mother. Bombay : Central Chinmaya Mission Trust.

Connolly, Peter (Editor). Aneka Pendekatan Studi Agama. Yogyakarta : LKiS.

Damsar. 2013. Pengantar Sosiologi Politik

(Edisi Revisi). Jakarta : Kencana Prenada Media Group.

Dana, I Wayan. 2008. Paruman Barong di Pura Pucak Padang Dawa Baturiti Tabanan : Perspektif Kajian Budaya (Disertasi). Denpasar : Program Doktor Program Studi Kajian Budaya Program Pascasarjana Universitas Udayana.

Debroy, Bibek dan Dipavali Debroy. 2001. Markandeya Purana. Surabaya : Penerbit Paramita.

Donder, I Ketut. 2009. Teologi : Memasuki Gerbang IImu Pengetahuan IImiah Tentang Tuhan, Paradigma Sanatana Dharma. Surabaya : Penerbit Paramita.

Dharmayuda, I Made Suasthawa. 1995. 
Kebudayaan Bali: Pra Hindu, Masa Hindu, dan Pasca Hindu. Denpasar : CV. Kayumas Agung.

Eatwell, Roger dan Anthony Wright. Ideologi

Politik Kontemporer (terjemahan).

Yogyakarta : Penerbit Jendela.

Geertz, Clifford. 2000. Negara Teater,

Kerajaan-kerajaan di Bali Abad

Kesembilan Belas (Terjemahan).

Yogyakarta : Yayasan Bentang Budaya.

Haryanto, Sindung. 2011. Sosiologi

Ekonomi. Jogjakarta : Ar-Ruzz Media.

Jones, PIP. 2009. Pengantar Teori-teori

Sosial. Jakarta : Yayasan Obor Indonesia.

Koentjaraningrat. 2005. Pengantar

Antropologi II, Pokok-pokok Etnografi.

Jakarta : Rineka Cipta.

Koentjaraningrat. 2009. Pengantar IImu

Antropologi (Edisi Revisi). Jakarta :

Rineka Cipta.

Koentjaraningrat. 2010. Sejarah Teori

Antropologi I. Jakarta : Penerbit Universitas Indonesia (UI Press).

Pandit, Bansi. 2009. The Hindu Mind :

Fundamentals of Hindu Religion and

Philosophy for All Age. New Delhi :

New Age Books.

Perlas, Nicanor. 1999. Shaping

Globalization : Civil Society, Cultural Power and Threefolding. Quezon City, Philipines : Co-published by CADI Philipines and GlobeNet3 USA.
Priyono, B. Herry. 2003. Anthony Giddens, Suatu Pengantar. Jakarta : Kepustakaan Populer Gramedia.

Ritzer, George dan Douglas J. Goodman.

2007. Teori Sosiologi Modern. Jakarta

: Kencana Prenada Media Group.

Sairin, Sjafri, Pujo Semedi, dan Bambang

Hudayana. 2002. Pengantar

Antropologi Ekonomi. Yogyakarta :

Pustaka Pelajar.

Sivananda, Swami. 2001. The Devi

Mahatmya. Shivanandagar India :

Swami Krishnananda for The Devine Life Society.

Sudarsana, K dan I Wayan Widarsana. 2009.

Pura Kahyangan Jagat Luhur Natar

Sari. Tabanan : Desa Adat Apuan.

Sukanara, I Made. 1993. Tapakan Ida

Bhatara ring Natar Sari - Apuwan

(Salinan Lontar). Denpasar : Kantor

Dokumentasi Budaya Bali.

Sukarsa, I Made. 2005. Pengaruh

Pendapatan Keluarga dan Pemahaman

Agama Terhadap Pengeluaran

Konsumsi Ritual Masyarakat Hindu di

Bali Ditinjau dari Berbagai Dimensi

Waktu. (Disertasi). Surabaya

Universitas Airlangga.

Surbakti, Ramlan. 2013. Memahami Ilmu

Politik. Jakarta : Grasindo.

Weber, Max. 2006. Etika Protestan \& Spirit Kapitalisme (Terjemahan). Yogyakarta : Pustaka Pelajar. 
Wibawa, Made Aripta. 2007. Ibu Durga, Ibu Suci (Kekuatan dan Keajaiban). Surabaya : Penerbit Paramita.

Wijaya, I Wayan Kandi. 2012. "Manajemen Karya Agung Panca Balikrama Di Pura Besakih Dan Implikasinya Terhadap Kehidupan Sosial-Ekonomi Masyarakat Besakih Kabupaten Karangasem Provinsi Bali" (Disertasi). Denpasar : Universitas Hindu Indonesia. 